\title{
Transvaginal repair of ureteral transection post gynecological surgery: a case report
}

\section{Reparo transvaginal de transecção ureteral após cirurgia ginecológica: relato de caso}

Andreisa Paiva Monteiro Bilhar ${ }^{1}$. Thais Fontes de Magalhães ${ }^{2}$. Leonardo Robson Pinheiro Sobreira Bezerra ${ }^{1}$. Sara Arcanjo Lino Karbage ${ }^{1}$. José Ananias Vasconcelos Neto ${ }^{1,3}$. Kathiane Lustosa Augusto ${ }^{1}$.

1 Maternidade Escola Assis Chateaubriand(MEAC), Universidade Federal do Ceará(UFC), Fortaleza, Ceará, Brasil. 2 Universidade de São Paulo (USP), São Paulo, Brasil. 3 Hospital Geral de Fortaleza (HGF), Fortaleza, Ceará, Brasil.

\begin{abstract}
Introduction: Ureteral injuries are relatively common in gynecological procedures. The repair of such injuries has traditionally been done through open surgery; however, minimally invasive techniques have become an option in some cases. We report the case of a ureteroureteral anastomosis successfully transvaginally approached. Case report: a 70-year-old woman developed hydronephrosis and acute renal failure after vaginal hysterectomy, parametrectomy, McCall culdoplasty, sacrocolpopexy, posterior colpoplasty and perineoplasty. She was reoperated, and had bilateral ureteral injuries correctly identified and repaired through the vaginal route. Discussion: Difficulties encountered during transvaginal surgery include ureter identification and the narrow surgical field. In order for a vaginal repair to be performed, surgeons must have expertise with vaginal surgery and know the anatomy of the ureter as seen through the vagina. Additionally, JJ stents can be used to facilitate repair. Conclusion: Vaginal repair of ureteral injuries is feasible and has potentially less morbidity than the standard abdominal approaches, but further studies are needed in order to determine its efficacy and complication rates.
\end{abstract}

Keywords: Ureter. Gynecologic surgical procedures. Surgical procedures, operative.

\section{RESUMO}

Introdução: Lesão ureterais são relativamente comuns em procedimentos ginecológicos. Seu reparo tem sido tradicionalmente feito por cirurgia aberta, porém, técnicas minimamente invasivas têm se tornado opção em casos selecionados. Reportamos aqui o caso de uma anastomose uretero-ureteral realizada via vaginal. Relato de caso: Uma mulher de 70 anos evoluiu com hidronefrose e falência renal aguda após procedimento uroginecológico. Durante a reabordagem, foram identificadas lesões ureterais bilaterais, sendo as mesmas corrigidas pela via vaginal. Discussão: Dificuldades encontradas durante a abordagem vaginal de tais lesões incluem a identificação do ureter e o campo cirúrgico reduzido. Tal abordagem é possível se o cirurgião tem experiência com cirurgia vaginal e conhece a anatomia do ureter vista por esse campo. O cateter ureteral pode ser usado para facilitar tal reparo. Conclusão: O reparo via vaginal de lesões ureterais é factível e tem, potencialmente, menor morbidade que a abordagem abdominal; porém, mais estudos são necessários para determinar sua eficácia e taxas de complicação.

Palavras-chave: Ureter. Procedimentos cirúrgicos em ginecologia. Procedimentos cirúrgicos operatórios.

Corresponding author: Thais Fontes de Magalhães, Hospital das Clínicas, Avenida Dr. Enéas Carvalho de Aguiar, 255, 10 andar, São Paulo, São Paulo. CEP: 05403-000. Telefone: +55 85 99700-5858. E-mail: thaisfdemagalhaes@gmail.com

Conflict of interests: The authors have no conflicts of interest to declare.

Received: 13 Aug 2018; Revised: 01 Oct 2018; Accepted: 03 Oct 2018. 


\section{INTRODUCTION}

Although rare in most surgeries, ureteral lesions are relatively common complications of gynecological procedures. ${ }^{1}$ The ureter is located 2-3 centimeters to the side of the cervix uteri, which makes it especially vulnerable to being injured or obstructed. ${ }^{2}$ Gynecological interventions account for 52 to $82 \%$ of reported ureteral injuries, ${ }^{1,3}$ and the incidence of ureteral lesions ranges from approximately $0.04 \%$ to $11 \%$ in gynecological surgeries. ${ }^{1,4-7}$ Ideally, ureteral injuries should be identified and treated intraoperatively. Nonetheless, most injuries go unnoticed until the postoperative period, ${ }^{3}$ when patients present clinical symptoms such as lower back pain, nausea or vomiting; or findings suggestive of peritonitis, fever or leukocytosis. ${ }^{2}$ If a lesion is suspected in the postoperative period, an excretory urography could be ordered, although ultrasound and computerized tomography (CT) may also show hydronephrosis or an intra-abdominal abscess. ${ }^{8}$ Delays in diagnosis of such injuries may lead to significant scarring and renal failure.

Repair has traditionally been done through open surgery. However, recent developments in pelvic and laparoscopic surgery, along with the known benefits of minimally invasive procedures, suggest that using less invasive approaches may be an option in such cases. ${ }^{2}$ In this article, we report the case of a ureteroureteral anastomosis, successfully approached transvaginally, to correct bilateral ureteral injuries in a patient who had previously undergone gynecologic surgery. Ethics committee approval has been obtained for this report at Hospital Geral de Fortaleza.

\section{CASE REPORT}

A 70-year-old female, referred to our service due to a 2-year history of uterine prolapse associated with urinary incontinence symptoms, underwent vaginal hysterectomy, parametrectomy, McCall culdoplasty, posterior colpoplasty and perineoplasty. On post-operative day one, the patient was anuric. Pelvic examination revealed no apparent fistulas, while a sonogram of the urinary tract showed bilateral hydronephrosis and little to no urine in the bladder. Serum creatinine levels were 7.2 $\mathrm{mg} / \mathrm{dl}$ and blood urea nitrogen (BUN) levels were $42.1 \mathrm{mg} / \mathrm{dl}$.

This patient was then reoperated in order to have JJ stents placed (Figures 1 and 2) and the ureteric reanastomosis performed (Figure 3). On litothomy position and under general anesthesia, we intended to proceed with cystoscopy to catheterize the ureters; however, the cystoscope failed to pass. Using a vaginal approach, the sutures in the posterior vaginal wall and vaginal cuff were then removed. Through this view, sectioned portions of the right ureter were identified, a JJ stent was placed, and the ureter was reanastomosed terminoterminally. Following, a partial section in the left ureter was identified, a JJ stent was again placed on this side, and the left ureter was likewise anastomosed. A cystoscopy was then performed, and the end of both JJ stents were visualized exiting the ureteral os (orifice). The surgical field was then inspected and the vaginal mucosa was sutured.
Figura 1. Transvaginal JJ stent insertion in the individualized ureter.

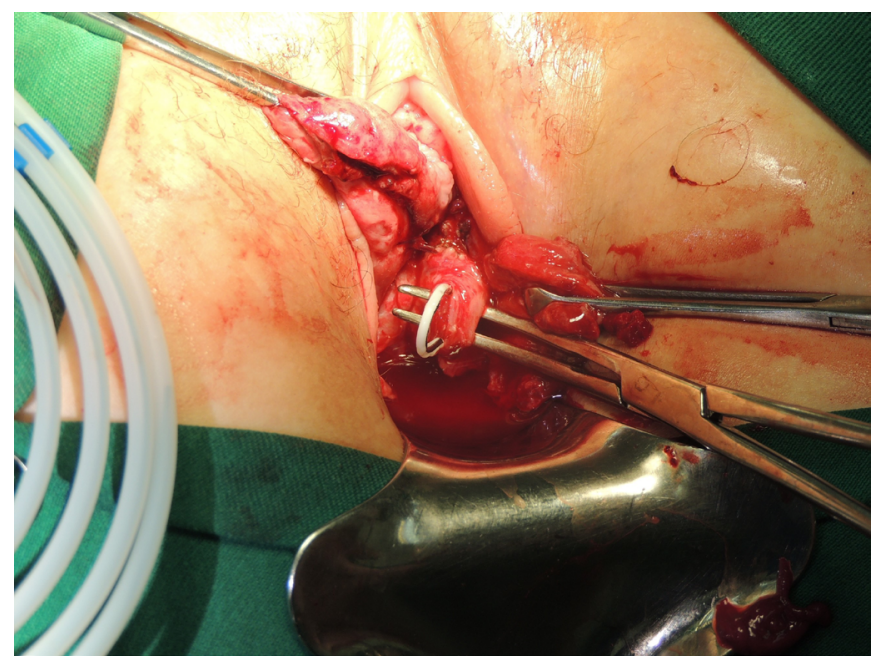

Figura 2. Transvaginal view of the individualized ureter (with JJ stent), before being reanastomosed (shown with Adson forceps).

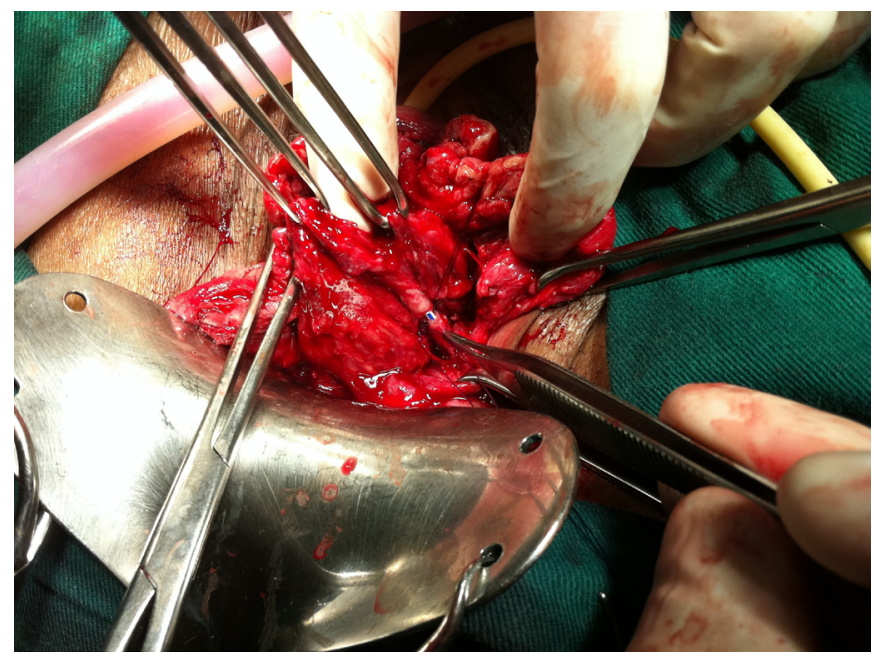

Figura 3. Individualized ureter after transvaginal reanastomosis (shown with Mixter forceps).

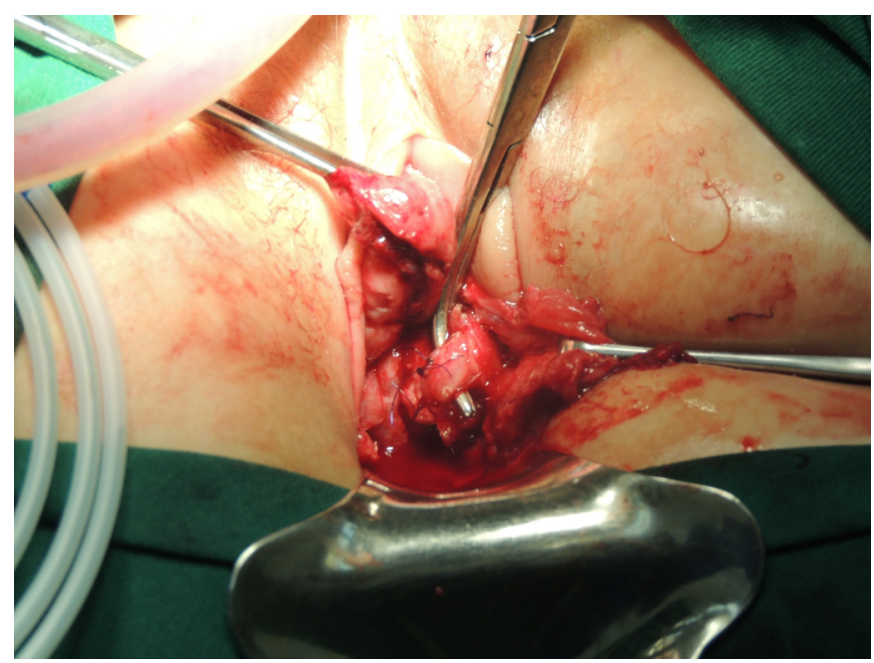


Her acute renal failure significantly improved, and this patient presented with spontaneous diuresis on the first day after her second surgery. On post-operative day three, new laboratory exams showed BUN and serum creatinine levels of $15.2 \mathrm{mg} /$ $\mathrm{dl}$ and $1.2 \mathrm{mg} / \mathrm{dl}$, respectively. A new sonogram showed left-sided pielectasis and JJ stents correctly placed. This woman was discharged and continued to receive outpatient care, with normal kidney function at follow-up.

\section{DISCUSSION}

Ureteral injuries are potential complications of gynecologic procedures. $^{9} \quad$ Its incidence varies greatly depending on the procedure performed: from $0.04-2 \%$ in vaginal hysterectomies, ${ }^{1,4} \quad 0.3-1.3 \%$ in robotic/laparoscopic hysterectomy ${ }^{4,10}$ and $0.18 \%-1 \%$ in abdominal hysterectomies ${ }^{4,5}$, to $1-11 \%$ in uterosacral ligament colposuspension. ${ }^{6,7,11} \mathrm{~A}$ study in a tertiary-level care center showed that ureteral repair was needed in $0.26 \%$ of the 6422 patients studied, all of which had undergone gynecologic surgeries. Indications for surgery in $29.5 \%$ of cases occurred due to partial or total transection, or to the formation of fistulas. Likewise, another research analyzed 80 patients with ureteral injuries post gynecologic surgeries and reported that $67.9 \%$ had associated vesicovaginal fistula (VVF), 14.8\% had ureteral ligations, 10\% had ureterovaginal fistulas and $2.4 \%$ had ureteral scarring. ${ }^{12}$ Although symptom onset and diagnosis of ureteric injury are often delayed following surgery, ${ }^{8,13}$ its diagnosis in the postoperative period is associated with significant scarring and may lead to difficulty in choosing the best surgical approach for its correction. ${ }^{2}$ Commonly, ureteral injuries are corrected through ureteroneocistostomy, ureteroureterostomy, fistula closing, nephrectomy, JJ stents insertion, or Boari's operation; in most cases, using the abdominal route. ${ }^{8}$ The vaginal approach, however, can provide a minimally invasive option for managing some injuries, possibly avoiding percutaneous nephrostomy and a second operation for ureteral reimplantation. ${ }^{11}$ If it is feasible to remove the obstruction transvaginally, vaginal techniques are less invasive, better tolerated and less morbid than the standard abdominal approach, particularly if there are adhesions from previous abdominal surgery. ${ }^{11,14}$ A vaginal

\section{REFERENCES}

1. Burks FN, Santucci RA. Management of iatrogenic ureteral injury. Ther Adv Urol. 2014;6(3):115-24.

2. Kalisvaart JF, Finley DS, Ornstein DK. Robotic-assisted repair of iatrogenic ureteral ligation following robotic-assisted hysterectomy. JSLS. 2008;12(4):414-6.

3. Lee JS, Choe JH, Lee HS, Seo JT. Urologic complications following obstetric and gynecologic surgery. Korean J Urol. 2012;53(11):795-9.

4. Packiam VT, Cohen AJ, Pariser JJ, Nottingham CU, Faris SF, Bales GT. The impact of minimally invasive surgery on major iatrogenic ureteral injury and subsequent ureteral repair during hysterectomy: a national analysis of risk factors and outcomes. Urology. 2016;98:183-8. approach to ureteric repair is less traumatic and should be considered whenever possible. ${ }^{8}$ Despite this, there are few reports in the literature concerning ureteral anastomosis done transvaginally to correct iatrogenic ureteral lesions. In our patient, we managed to perform a minimally invasive procedure, with a good surgical field that allowed for the identification and repair of such injury, while still maintaining low morbidity levels. We highlight that, in this case, such lesion occurred after a gynecologic procedure that was itself done vaginally, which thus facilitated this approach.

Difficulties encountered during transvaginal surgery include the narrow surgical field, especially in young, nulipara females; and ureter identification. ${ }^{14}$ In order for a vaginal repair to be performed, surgeons must know the anatomy of the ureter as seen through the vagina. Measures that facilitate the identification and repair of the ureter include development of the paravesical space, dissection of certain tissues with a weak phenylephrine hydrochloride solution, and passing of a catheter by cystoscopy up to the injured ureter. ${ }^{15}$ Catether insertion was also used by other surgeons ${ }^{8,14}$ to improve operative exposure; they suggested that an indwelling urethral catheter in addition to temporary ureteral stents help in the identification of structures and facilitate dissection and that, in order for a vaginal approach for repair to be possible, the ureteric orifice must be seen and catheterized. ${ }^{8}$ Infiltrating the vaginal mucosa with a solution also facilitates tissue dissection. $^{14}$

\section{CONCLUSION}

Transvaginal surgery can be considered an option in selected cases where there has been failure of the conservative treatment of iatrogenic ureteral lesions, in patients in whom the ureter can be visualized through the vaginal route and in surgical teams with expertise in vaginal surgery. It is a feasible procedure with potentially less morbidity than the standard abdominal approach. However, further studies are needed in order to compare the efficacy and complication rates of this approach with other techniques available (laparoscopic, robotic and open).

5. Ramdhan RC, Loukas M, Tubbs RS. Anatomical complications of hysterectomy: a review. Clin Anat. 2017;30(7):946-52.

6. Karram M, Goldwasser S, Kleeman S, Steele A, Vassallo B, Walsh P. High uterosacral vaginal vault suspension with fascial reconstruction for vaginal repair of enterocele and vaginal vault prolapse. Am J Obstet Gynecol. 2001;185(6):1339-42; discussion 1342-3.

7. Shull BL, Bachofen C, Coates KW, Kuehl TJ. A transvaginal approach to repair of apical and other associated sites of pelvic organ prolapse with uterosacral ligaments. Am J Obstet Gynecol. 2000;183(6):1365-73; discussion 1373-4.

8. Raassen T, Ngongo CJ, Mahendeka MM. Diagnosis and management of 365 ureteric injuries following obstetric and 
gynecologic surgery in resource-limited settings. Int Urogynecol J. 2018;29(9):1303-9.

9. Selzman AA, Spirnak JP. Iatrogenic ureteral injuries: a 20-year experience in treating 165 injuries. J Urol. 1996;155(3):878-81.

10. Brummer TH, Jalkanen J, Fraser J, Heikkinen AM, Kauko M, Makinen J, et al. FINHYST, a prospective study of 5279 hysterectomies: complications and their risk factors. Hum Reprod. 2011;26(7):1741-51.

11. Siddighi S, Yandell PM, Karram MM. Delayed presentation of complete ureteral obstruction deligated transvaginally. Int Urogynecol J. 2011;22(2):251-3.
12. Bouya PA, Odzebe AW, Otiobanda FG, Itoua C, MahoungouGuimbi K, Banga MR, et al. [Urological complications of gynecologic surgery]. Prog Urol. 2011;21(12):875-8. Article in French.

13. Harkki-Siren P, Sjoberg J, Tiitinen A. Urinary tract injuries after hysterectomy. Obstet Gynecol. 1998;92(1):113-8.

14. Farhan B, Okhunov Z, Kaplan A, Ghoniem G. Transvaginal excision of bilateral single ureteral stumps of refluxing ectopic ureters in an adult female with urinary incontinence. Urology. 2015;86(1):192-5.

15. Thompson JD, Benigno BB. Vaginal repair of ureteral injuries. Am J Obstet Gynecol. 1971;111(5):601-10.

\section{How to cite:}

Bilhar AP, Magalhães TF, Bezerra LR, Karbage SA, Vasconcelos JA Neto, Augusto KL. Transvaginal repair of ureteral transection post gynecological surgery: a case report. Rev Med UFC. 2019 abr-jun;59(2):62-65. 